\title{
Errors in anthropometric measurements in neonates and infants
}

\author{
D Harrison, Carinus Nursing College, Groote Schuur Hospital \\ H Harker, Carinus Nursing College, Rondebosch Cottage Hospital \\ H D V Heese, MD, Institute of Child Health, University of Cape Town \\ MD Mann, PhD, Institute of Child Health, University of Cape Town \\ J Berelowitz, MSc, Institute of Child Health, University of Cape Town
}

\begin{abstract}
The accuracy of methods used in Cape Town hospitals and clinics for the measurement of weight, length and age in neonates and infants became suspect during a survey of 12 local authority and 5 private sector clinics in 1994-1995 (Harrison et al. 1998). A descriptive prospective study to determine the accuracy of these methods in neonates at four maternity hospitals [ 2 public and 2 private] and infants at four child health clinics of the Cape Town City Council was carried out.

The main outcome measures were an assessment of three currently used methods namely to measure crown-heel length with a measuring board, a mat and a tape measure; a comparison of weight differences when an infant is fully clothed, naked and in napkin only; and the differences in age estimated by calendar dates and by a specially designed electronic calculator.

The results showed that the current methods which are used to measure infants in Cape Town vary widely from one institution to another. Many measurements are inaccurate and there is a real need for uniformity and accuracy. This can only be implemented by an effective education program so as to ensure that accurate measurements are used in monitoring the health of young children in Cape Town and elsewhere.
\end{abstract}

\section{Abstrak}

Die akkuraatheid met die meet van lengte, gewig en ouderdom in sekere kraamhospitale en babagesonheidsklinieke in Kaapstad het verdag voorgekom tydens ' $n$ opname in 1994-1995(Harrison et al., 1998).

"n Beskrywende prospektiewe studie is gebruik om foute te bepaal met hierdie meetings op pasgeborenes in vier kraamhospitale ( 2 staats-en 2 privaathospitale) en babas wat 4 van Kaapstad se Stadsraad se babagesondheidsklinieke bywoon.

Die maatstawwe van drie metodes vir die meet van lengte van die kroontjie tot haakskeen is ondersoek, naamlik met ' $n$ meetplank, meetmat en maatband. Babas is geweeg ten volle geklee, net met ' $n$ doek aan, of kaal. Die beraamde ouderdom van die babas is bereken deur gebruik te maak van 'n kalender en met ' $n$ spesiale elektroniese rekenaar.

Die resultate toon dat metodes van meting van lengte, gewig en bepaling van ouderdom in Kaapstad varieer van een instansie tot ' $\mathrm{n}$ ander.

Eenvormige metodes van hierdie metings en doeltreffende opvoedkundige programme is nodig om huidige gebruike, wat met groot foute geassosieer word, uit te skakel. Alleen dan sal dié van nut wees in die bepaling van die gesondheid van jong kinders in Kaapstad.

\section{Introduction and problem statement}

Measurements of weight-for-age, height-for-age and head circumference-for-age form a basis for growth monitoring in South African pre-school children. They are important because of the prevalence of intra-uterine growth retardation (Malan et al.,1967; Jaroszewics et al.,1975 ; Woods et al.,1981) stunting and weight-for-age deficits (Solarsh et al.,1994) in this population. These measurements are plotted on the Road to Health (RTH) card which is pivotal in the early identification of deviations from normal. However the quality of the recorded data has been questioned (Kuhn et al., 1990).

In a recent Cape Town survey (Harrison et al.,1998) we noticed that some infants at local public clinics were weighed with clothes and others without clothes. No standard method was followed. The results that were plotted on the RTH card were often imprecise thereby negating the value of health monitoring. Observations at a selection of public hospitals and midwife obstetric units, showed that birth length was seldom measured and no uniform method was used.

This study was designed to determine the accuracy of infant measurements and age determination as used in a variety of maternity hospitals and child health clinics in Cape Town.

\section{Research design and methodology}

The study was conducted in 1997 at four child health clinics of the Cape Town City Council and four maternity hospitals (two private and two Provincial Administration institutions). These were selected at random as the infants offered a reasonable cross section of the main population groups of Cape Town. The methods currently used in these institutions to determine length, weight and age were evaluated by two observers (D.H., H.H.). The relevant measurements were made by the resident nursing staff. There was no selection of babies for measurement. Babies at clinics were seen in order of ar- 
rival. In the maternity hospitals the observer watched the routine measurements of normal fullterm infants in a ward.

The reference standards for weight and length were based on the recommendations of the Human Growth Foundation (Falkner, 1995) ie naked weight on a calibrated scale and length determined with a measuring board. Chronological age was checked with a specially designed electronic calculator. This accurate instrument served as the reference standard for estimations that had been determined by calendar dates.

The main outcome measures were:
Table 1. Measurements in centimetres made with Mat and Board

\begin{tabular}{|l|l|l|l|}
\hline & Mean & SD & $\mathrm{N}$ \\
\hline Mat & 55.1 & 11.2 & 50 \\
\hline Board & 54.7 & 10.9 & 50 \\
\hline Difference & & & \\
\hline Nurse 1 & -0.08 & 1.40 & 50 \\
\hline Nurse 2 & 0.58 & 0.57 & 12 \\
\hline Nurse 3 & -0.76 & 1.71 & 17 \\
\hline Nurse 4 & -0.20 & 1.62 & 10 \\
\hline
\end{tabular}

\section{Length}

Three methods of measuring crown-heel length were encountered in these institutions:

Measuring board: An infant was placed supine in a standard wooden measuring board with the crown of the head touching the upright end. The legs were extended and a sliding board was brought up to the feet which were kept vertical on the surface. Length was read on a metal scale to the nearest millimetre.

Measuring mat (Nestlé): A calibrated plastic pad was unrolled onto a level working surface and the supine infant was positioned with the crown of the head against the upper board. The legs were extended and length was recorded to the nearest millimetre at the junction of the heel and mat.

Tape measure: The infant was placed on his/her left or right side on a flat surface. A plastic measuring tape was extended from the crown of the head to the heel following the curves of head, trunk and legs. Length was recorded to the nearest millimetre.

The differences between measurements made using these methods were determined as follows:

Measuring mat versus measuring board: Fifty infants ranging in age from 1 week to 7 months were measured twice by each method. The study was performed by four professional nurses who used each technique and were witnessed by an independent observer (DH).

Measuring mat versus tape measure: Twenty neonates were measured by two professional nurses who used each method twice.

\section{Weight}

Thirty infants ranging from 0.4 to 5.5 months were weighed in clothes but without shoes, hats or bibs. This process was repeated in dry napkins only, either disposable ones or the towelling variety with a liner. Finally the infants were weighed naked using the recommended technique. The weights were recorded in kilograms to the nearest $10 \mathrm{~g}$. An electronic scale was used (Tanita, Model 1583). Its accuracy was checked against weights of a known measure and it was calibrated

\section{Figure 1 Difference between Mat and Tape measures}

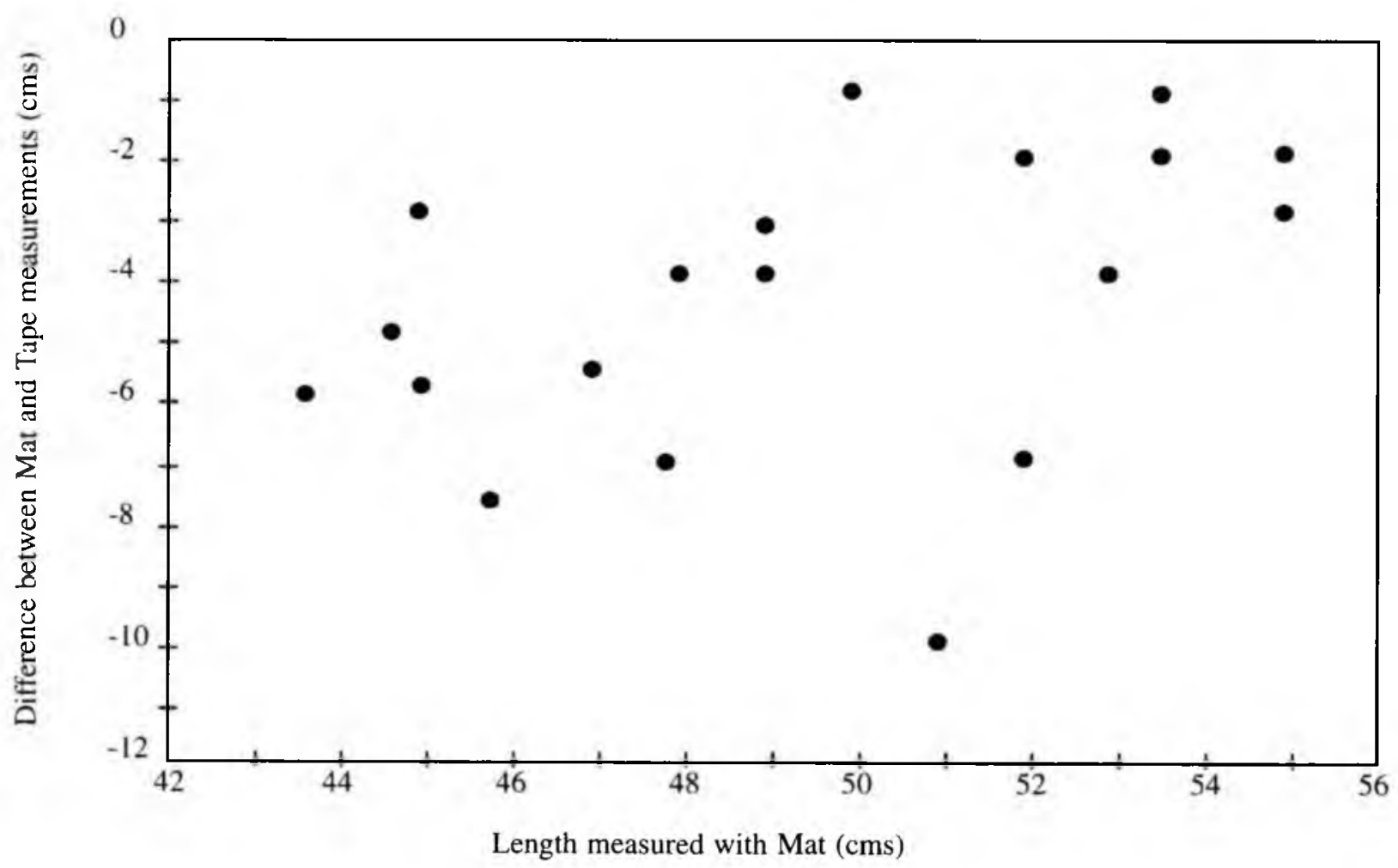




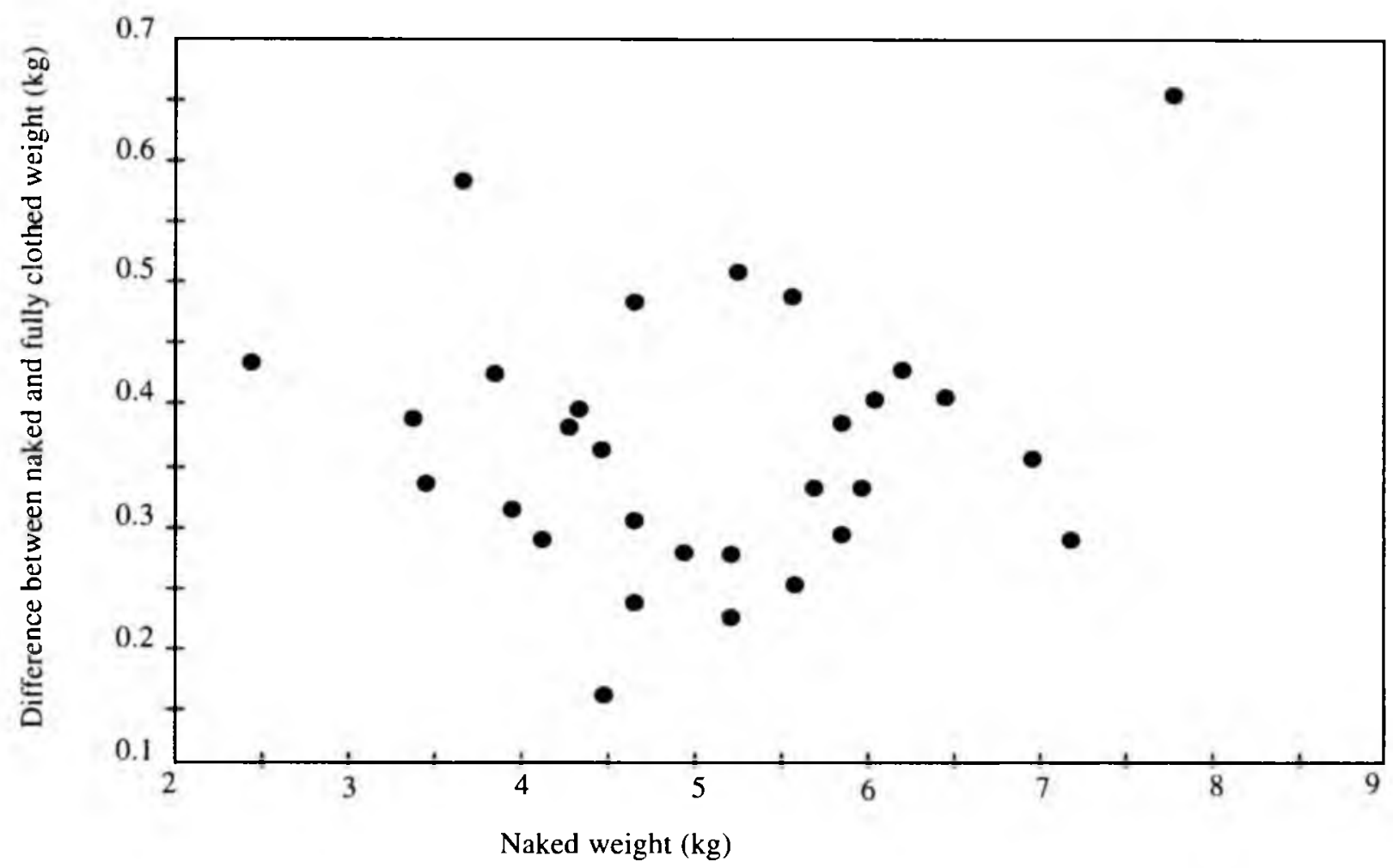

every six months by a mobile maintenance service. The procedure was conducted by a child health clinic nurse and witnessed by an independent observer $(\mathrm{HH})$.

\section{Age}

The clinic nurse also calculated the age of each of the 30 infants from the date of birth to the date of weighing by using a calendar. The ages were checked by the observer who used a specially designed electronic calculator.

\section{Statistics}

The mean of all duplicate measurements was used for subsequent analysis with Statistica version 5.197 edition. (StatSoft, Inc. (1995). STATISTICA for Windows (Computer program manual). Tulsa, OK: StatSoft, Inc., Tulsa, OK.). ANOVA was used to test for differences in length measured with the mat and board by the 4 nurses taking the measurements. The results with the mat and tape were compared with the paired t-test.

\section{Figure 3 Error if baby is weighed in a nappy}

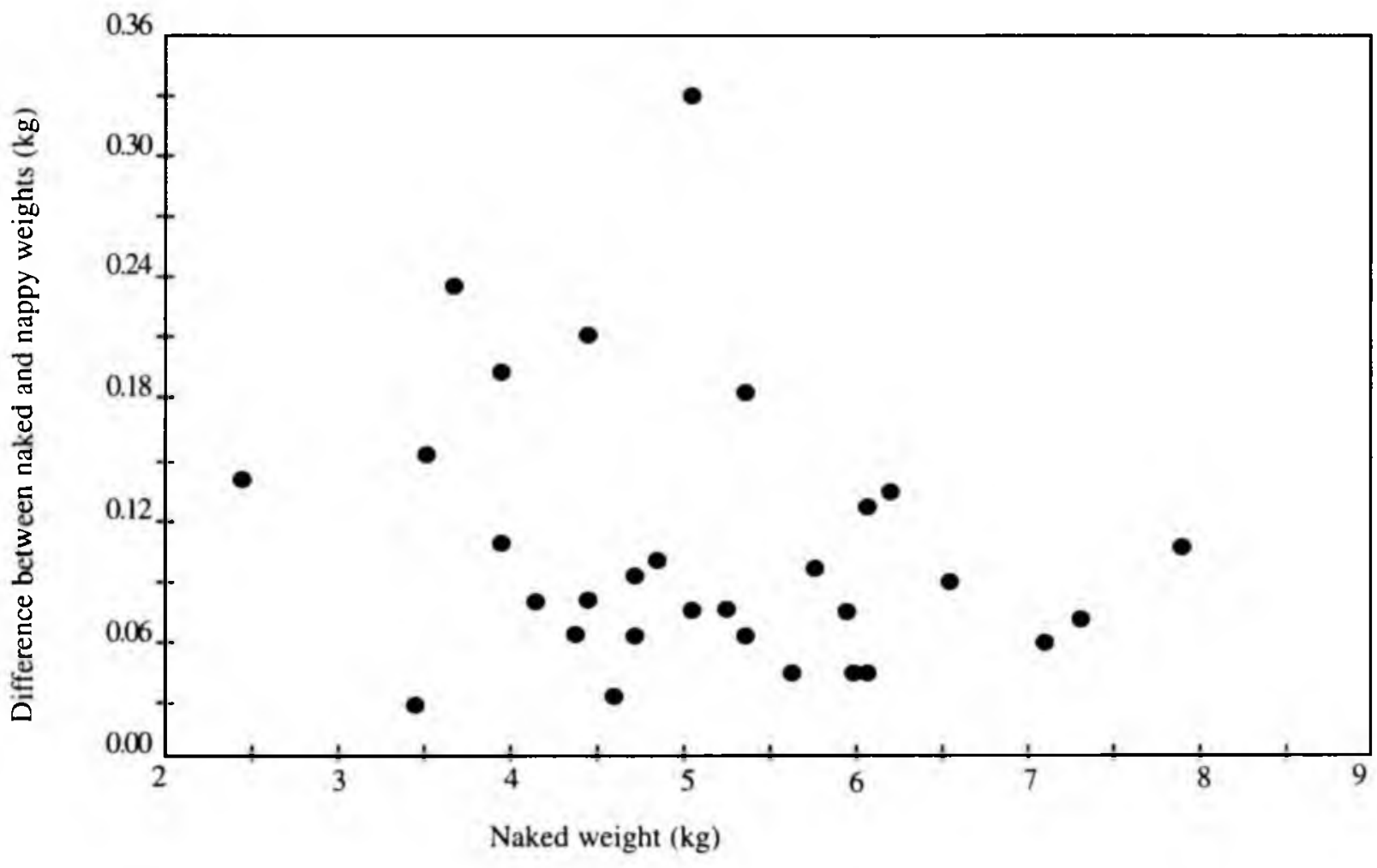


Results

\section{Length}

Measuring board versus mat: (Table 1) Overall the two methods gave comparable results (mean difference $0.08 \mathrm{~cm}, \mathrm{SD} \mathrm{1.40)}$ ). There were differences between the measurements by the 4 nurses $(F=2.98, p<0.05)$. Two nurses obtained longer measurements with the mat and two with the board.

Measuring mat versus tape: Measurements with the same tape overestimated length by 1 to $10 \mathrm{~cm}$ (mean 4.3 $\mathrm{cm}, \mathrm{SD} 2.5, \mathrm{t}=7.77, \mathrm{p}$ $<0.0001)$ and introduced errors up to $20 \%$. The difference increased with increasing length (Figure 1). There was also interobserver variability. The tape measurements of one nurse overestimated length by between 1 and $5.5 \mathrm{~cm}$ (mean $2.8 \mathrm{~cm}, \mathrm{SD} \mathrm{1.8)}$ ) and those of the other nurse by 3.2 to $10 \mathrm{~cm}$ (mean $6.5 \mathrm{~cm}, \mathrm{SD} 2.4$ ).

\section{Weight}

The error introduced by weighing the baby fully clothed (Figure 2) was between 0.15 to $0.65 \mathrm{~kg}$ (mean $0.35 \mathrm{~kg}$, SD 0.11 ). Expressed as a percentage of the nude weight it ranged from $3.3 \%$ to $17.1 \%$ (mean $7.3 \%$, SD 3.2). Removing all clothing other than the nappy (Figure 3 ) reduced the overestimate to between 0.03 and $0.3 \mathrm{~kg}$ (mean $0.10 \mathrm{~kg}, \mathrm{SD} 0.07$ ) or $0.7 \%$ to $6 \%$ (mean $2.2 \%$, SD 1.6). While conducting our first survey (Harrison et al., 1998) we found that mothers and nursing staff were reluctant to undress infants in cold draughty clinics.

\section{Age}

There were appreciable errors in the calendar calculations (Figure 4). If expressed as a percentage of the actual age some of the errors were as large as $16 \%$.

\section{Discussion and recommendations}

One of the objectives of the RTH card is the early detection of deviations from normal growth. This requires accurate and reproducible measurements using standardised techniques. This study shows serious deficits in the way growth is measured in some Cape Town hospitals and child health clinics.

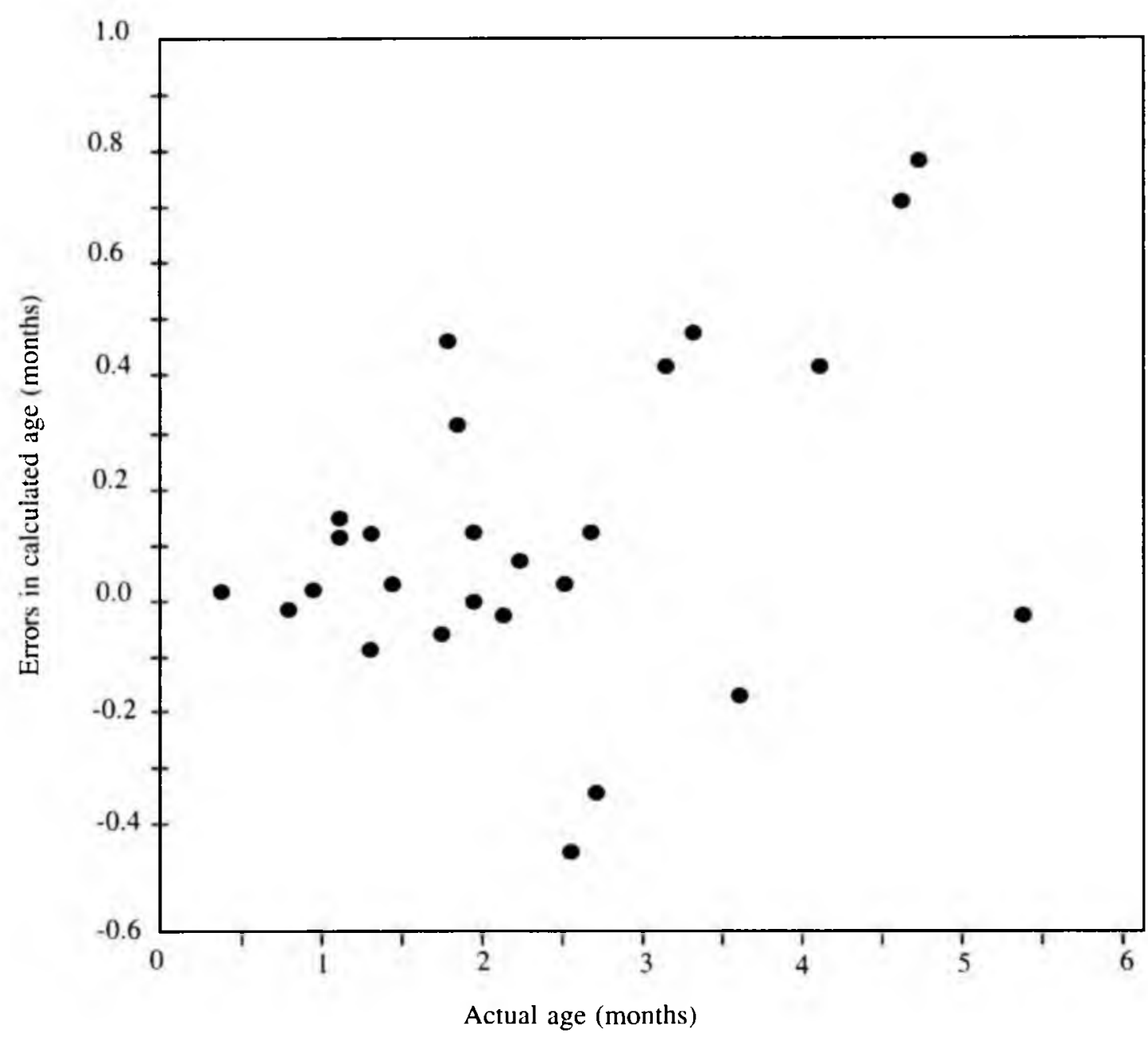

\section{Length}

Recumbent length should yield consistent readings and cannot be measured accurately with a tape measure. The latter was used in several institutions without defining the reference points or the method. Even a standardised method overestimated length by as much as $20 \%$. The Human Growth Foundation (Falkner 1995) recommends a measuring board for accuracy and the assistance of a parent to hold the crown of the infant's skull against the headboard while the measurer attends to the other details.

Recommendation: a measuring mat appears to be equally reliable and a suitable substitute at clinics that lack a board.

\section{Weight}

Weight, the most commonly used measurement is fraught with inaccuracies. Clothing, shoes and napkins vary in size and weight and produce errors up to $17 \%$. The removal of all but a napkin decreased the error but does not eliminate it and only nude weight is acceptable.

An Australian study (Alsop-Shields and Alexander 1997) reported that error due to scales and technique was small but biological factors in the baby such as milk intake, stool and urine output, and external factors such as clothing caused considerable errors. A baby weighed naked at two consecutive clinic visits needed to have gained or lost at least 150 grams for a real change to be detected. This prompted the recommendation that infants under 9 months of age be weighed naked but no more than two-weekly and the older 
ones no more than monthly.

An inaccurate weight can be compounded by incorrect plotting. This is of particular concern with the RTH growth chart. It has three reference curves. The median is the $50^{\text {th }}$ percentile for boys, the upper curve the $97^{\text {th }}$ percentile for boys and the lower curve the $3^{\text {rd }}$ percentile for girls. Both sexes are plotted on this graph although their weight patterns differ. The scale of the chart also makes it difficult to plot with accuracy the growth of an infant whose weight is below the $3^{\text {rd }}$ percentile.

Recommendation: Steps must be taken to ensure that all clinics have a stable, comfortable environmental temperature with no draughts. This environment would encourage parents to undress their infants. Different charts for boys and girls should be employed to produce a meaningful assessment of the health and nutritional status of an infant.

\section{Age}

Cooney et al, 1994 noted that estimations of age produce the most significant errors. Miscalculations result from a failure to correct for prematurity or because calendar dates are misread. Inaccuracies abound $(28.5 \%)$ when age is plotted on the horizontal axis of a growth graph irrespective of whether weight, length or head circumference are being assessed. This is probably related to the difficulty of adjusting to a logarithmic scale as errors seldom occur on the linear vertical scale. The authors express concern that inaccurate plots might elicit inappropriate responses from health personnel, which in turn may have medical-legal implications. They recommend electronic age calculators and possibly an improved chart design with different charts for boys and girls.

Recommendation: Efforts should be made to improve age calculation, where feasible by electronic means.

\section{Conclusions}

The methods currently used in Cape Town clinics and hospitals to determine length, weight and age are inconsistent and inaccurate and this reduces the health monitoring value of the RTH card. An education program that uses uniform accurate measurements; correct determination of age and plotting of findings on appropriate charts for girls and boys can only reverse this.

Health monitoring including nutritional surveillance will remain a costly and futile practice if measurements and growth plotting are faulty.

\section{Acknowledgements}

We thank the nursing staff and mothers of the child health clinics and the co-operation of the nursing staff of the nurseries of Maternity Hospitals. Nestlé generously donated measuring mats and equipment.

The survey was supported by a grant from the Rita and Bernard Brodie Research Fellowship. The assistance of Mrs Lynor Heuer, Ms Adele Pearce and Sister Monica Franck with the preparation of the manuscript is appreciated.

\section{References}

ALSOP-SHIELD L \& ALEXANDER H 1997 : A study of erros that can occur when weighing infants. Journal of Advances in Nursing 1997; 25:587-594

COONEY K; PATHAK U \& WATSON A 1994 : Infant growth charts. Archives Diseases of Childhood 1994: 71:159. 160 .

FALKNER F 1995 : Recommendations for monitoring growth in childhood: A human growth foundation committee report. International Child Health: A digest of current information 1995; VI: 79-85.

HARRISON D; HEESE HDEV; HARKER H \& MANN MD 1998 : An assessment of the 'Road-to-Health' card based on perceptions of clinic staff and mothers. South African Medical Journal 1998; 88: 1424-1428.

JAROSZEWICS AM; SCHUMANN DEW \& KEET MP

1975 : Intra-uteriene groeistandaarde van Kaapse Kleurling babas. South African Medical Journal 1975; 49: 568-572.

KUHN L \& ZWARENSTEIN M 1990 : Weight Information on the 'Road to Health' card inadequate for growth monitoring? South African Medical Journal 1990:78:495-496.

MALAN AF; EVANS A; SMIT WB DEV \& HEESE HDEV 1967 : Intra-uterine growth - a study of the birthweights of live-born infants. South African Medical Journal 1967;41:698-70.

SOLARSH GC; SANDERS DM; GIBSON CA \& GOUWS E 1994 : Community based survey versus sentinel site sampling in determining the nutritional status of rural children. South African Medical Journal 1994;84:747-752

WOODS DL; MALAN AF; HEESE HDEV \& VAN SCHALWYK DJ 1981 : Size at birth of infants born at term to coloured primiparas in Cape Town. South African Medical Journal 1981;60: 313-315. 